Article

MENEZES, P.H.S. ${ }^{1}$

ALBUQUERQUE, J.A.A. ${ }^{*}$ (D)

SMIDERLE, J.O. ${ }^{2}$

MEDEIROS, R.D. ${ }^{2}$

ALVES, J.M.A. ${ }^{1}$

GIANLUPPI, D. ${ }^{2}$

* Corresponding author:

<anchietaufrr@gmail.com>

Received: March 16, 2018

Approved: March 19, 2018

Planta Daninha 2019; v37:e019193014

Copyright: This is an open-access article distributed under the terms of the Creative Commons Attribution License, which permits unrestricted use, distribution, and reproduction in any medium, provided that the original author and source are credited.

\section{OccurRence of WeEds in Areas SubmitTed to Tillage Managements FOR SOYBean Cultivation IN THE Cerrado of Roraima}

\author{
Ocorrência de Plantas Daninhas em Áreas Submetidas a Manejos de Preparo \\ do Solo para Cultivo de Soja no Cerrado de Roraima
}

\begin{abstract}
Weeds from soils submitted to different tillage managements were identified in two consecutive years of soybean cultivation in the Cerrado of Roraima. The study was carried out in three areas: native area (NA), mechanically mowed native area (MA), and limed area (LA). A descriptive analysis of the phytosociological parameters relative density (Drr), relative frequency (Frr), relative dominance (Dor), importance value index (IVI), and index of relative importance (IRI) was performed to interpret the results. The weed similarity index (SI) was also calculated in the assessed areas. The highest relative frequencies were observed for Trachypogon plumosus (40.92\%), Bulbostylis capillaris (18.52\%), and Spermacoce capitata (18.33\%) in the native area and T. plumosus (24.69\%), Cyperus flavus (24.69\%), and S. capitata $(18.52 \%)$ in the mowed area. Among the species collected in the areas, the botanical families Poaceae, Cyperaceae, Fabaceae, and Rubiaceae are the most representative. The used managements contribute to the emergence of new species of spontaneous plants and weeds in the Cerrado of Roraima.
\end{abstract}

Keywords: Glycine max, phytosociological parameters, savanna.

RESUMO - Neste trabalho foram identificadas as plantas daninhas infestantes de solos submetidas a diferentes manejos de preparo, em dois anos consecutivos, para cultivo de soja no cerrado de Roraima. A pesquisa foi realizada em três áreas: área nativa $(\mathrm{AN})$, área nativa roçada mecanicamente $(\mathrm{AR})$ e área calcariada (AC). Para interpretação dos resultados, foi realizada a análise descritiva dos parâmetros fitossociológicos: densidade relativa (Drr), frequência relativa (Frr), dominância relativa (Dor), índice de valor de importância (IVI) e índice de importância relativa (IIR). Calculou-se, também, o Índice de Similaridade (IS) das plantas daninhas nas áreas dos manejos avaliados. Constatou-se que na área nativa as maiores frequências relativas (Frr) foram para as espécies Trachypogon plumosus (40,92\%), Bulbostylis capillaris (18,52\%) e Spermacoce capitata (18,33\%) e, na nativa roçada, para Trachypogon plumosus (24,69\%), Cyperus flavus (24,69\%) e Spermacoce capitata (18,52\%). Entre as espécies coletadas na área, as famílias botânicas Poaceae, Cyperaceae, Fabaceae e Rubiaceae são as que têm maior representatividade. Os manejos utilizados contribuem para o surgimento de novas espécies de plantas espontâneas e daninhas no cerrado de Roraima.

Palavras-chave: Glycine max, parâmetros fitossociológicos, savana.

${ }^{1}$ Universidade Federal de Roraima, Boa Vista-RR, Brasil; ${ }^{2}$ Empresa Brasileira de Pesquisa Agropecuária, EMBRAPA, Boa Vista-RR, Brasil. 


\section{INTRODUCTION}

Soybean is one of the main crops of the world agriculture because of its productive capacity, chemical composition, and nutritional value, which confers a plurality of uses in human and animal diet, with high socioeconomic importance. Brazil became the world's second largest soybean producer when its cultivation areas were expanded to the Cerrado. In the 2015/16 season, soybean production was of approximately 95 million tons of grains in an estimated area of 35 million hectares (Conab, 2016).

The Cerrado of Roraima covers approximately 4 million hectares and is part of the centralnortheast portion, forming part of the great Cerrado domain of northern Amazon, covering the extreme north of Brazil, Guyana, Venezuela, and Colombia. The relief is predominantly flat to smooth wavy, predominating Ultisols and Oxisols (Melo et al., 2010).

The State of Roraima is in the first steps of growth of the agricultural production in Brazil, moving towards the productive development of its main export product: soybean. In the 2014/15 season, the planted area was 16 thousand hectares, with an increase of approximately $40 \%$ in its planted area in the 2015/16 season, i.e., 25 thousand hectares of grains, representing a harvest above one million $60 \mathrm{~kg}$ bags.

Among the technologies are the complete soil correction, no-till use, and crop rotation, which require high initial investments, especially this region is an agricultural frontier where the market for production inputs is not yet disciplined (Gianluppi and Smiderle, 2016).

Weed identification is the first step to its control. The establishment of a weed community depends on local conditions, soil type, management practices, seed bank, and tillage management. The species stand out at each collection period due to several factors such as species characteristics, climate, seed bank, crop development, control period, and adopted planting system (Albuquerque et al., 2013).

This study aimed to identify the weed infestation of soils submitted to different soil tillage management in two consecutive years of soybean cultivation in the Cerrado of Roraima. The results of this research may be essential to define the weed management techniques agronomically and environmentally efficient in soil management systems adopted in the State of Roraima for soybean cultivation.

\section{MATERIAL AND METHODS}

An experiment of conventional planting was set up in May of the agricultural years of 2015 and 2016 at the Água Boa Experimental Field of the Embrapa Roraima, located at a distance of $30 \mathrm{~km}$ from the city of Boa Vista, capital of the State of Roraima, on the left margin of the BR-174, towards the city of Manaus, AM, with an approximate area of 1,200 ha between the geographical

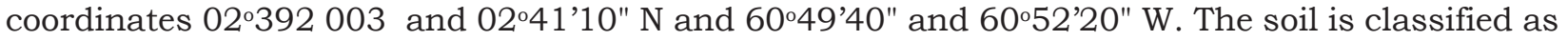
an Oxisol (dystrophic Yellow Latosol, LAdx, Brazilian Soil Classification System), representative of the Cerrado of Roraima (Benedetti et al., 2011), whose characteristics are shown in Table 1.

The study was carried out in an area of first and second years of cultivation, being a limed area (LA) under conventional planting system for soybean crop cultivation and a native area (NA) and a mechanically mowed native area (MA) on its sides. The dimensions of experimental plots were $50 \times 15\left(750 \mathrm{~m}^{2}\right)$ and the treatment areas had dimensions of $200 \times 15 \mathrm{~m}\left(3,000 \mathrm{~m}^{2}\right)$, totaling an area of $9,000 \mathrm{~m}^{2}$.

Table 1 - Chemical and physical characterization of the dystrophic Yellow Latosol at depths of 0-10 and 10-30 cm under native vegetation (without agricultural use) in a Cerrado area of Roraima before planting in 2015 and 2016

\begin{tabular}{|c|c|c|c|c|c|c|c|c|c|c|c|c|c|c|c|}
\hline \multirow{2}{*}{$\begin{array}{c}\text { Depth } \\
(\mathrm{cm}) \\
\end{array}$} & \multirow{2}{*}{$\begin{array}{c}\mathrm{pH} \\
\left(\mathrm{H}_{2} \mathrm{O}\right) \\
\end{array}$} & \multirow{2}{*}{$\begin{array}{c}\mathrm{C} \\
\left(\mathrm{g} \mathrm{kg}^{-1}\right) \\
\end{array}$} & \multirow{2}{*}{$\begin{array}{c}\mathrm{P} \\
\left(\mathrm{mg} \mathrm{kg}^{-1}\right) \\
\end{array}$} & $\mathrm{Ca}^{2+}+\mathrm{Mg}^{2+}$ & $\mathrm{K}^{+}$ & $\mathrm{Al}^{3+}$ & $\mathrm{H}+\mathrm{Al}$ & SB & CEC & $\mathrm{m}$ & $\mathrm{V}$ & \multirow{2}{*}{$\begin{array}{c}\text { Dens } \\
\left(\mathrm{kg} \mathrm{m}^{-3}\right) \\
\end{array}$} & Sand & Silt & Clay \\
\hline & & & & \multicolumn{6}{|c|}{$\left(\mathrm{cmol}_{\mathrm{c}} \mathrm{dm}^{-3}\right)$} & \multicolumn{2}{|c|}{$(\%)$} & & \multicolumn{3}{|c|}{$\left(\mathrm{g} \mathrm{kg}^{-1}\right)$} \\
\hline $0-10$ & 4.6 & 9.3 & 0.5 & 0.1 & 0.1 & 0.8 & 2.4 & 0.2 & 2.6 & 82.4 & 6.3 & 1.438 & 624 & 74 & 302 \\
\hline $10-30$ & 4.8 & 8.4 & 0.2 & 0.1 & 0.0 & 0.7 & 2.1 & 0.1 & 2.2 & 86.7 & 5.1 & 1.356 & 618 & 60 & 322 \\
\hline
\end{tabular}


For weed sampling, an iron square with dimensions of $0.50 \times 0.50 \mathrm{~m}$ was randomly placed 12 times at each experimental area (native, mowed, and limed). The collected weeds were cut close to the soil surface with pruning shears and machete, separated, identified, and quantified.

Initially, the class, family, scientific name, and common name of the weeds were identified. Subsequently, their type of propagation, growth habit, and life cycle were described and the dry matter (\%) was assessed. A descriptive analysis of the following phytosociological parameters was performed: relative density $($ Drr $)=$ species density $\times 100 /$ total density of all species; relative frequency $(\mathrm{Frr})=$ species frequency $\times 100 /$ total frequency of all species; relative dominance $($ Dor $)=$ species dry matter $\times 100 /$ total dry matter of all species; importance value index $($ IVI $)=$ Drr + Frr + Dor; and index of relative importance (IRI) $=$ IVI $\times 100 /$ total IVI of all species (Brandão et al., 1998).

Weed similarity index (SI) was calculated for the native (NA), mowed (MA), and limed areas (LA) and for common species among areas (NAMA, NALA, MALA, and NAMALA). The color symbology adopted in the Venni diagram (Figure 1) was based on their interaction, i.e., when a color is mixed with another or more colors, generates a new one. Jaccard's index of similarity (Brower and Zar, 1984) was used to estimate the percentage of common species in the three areas.

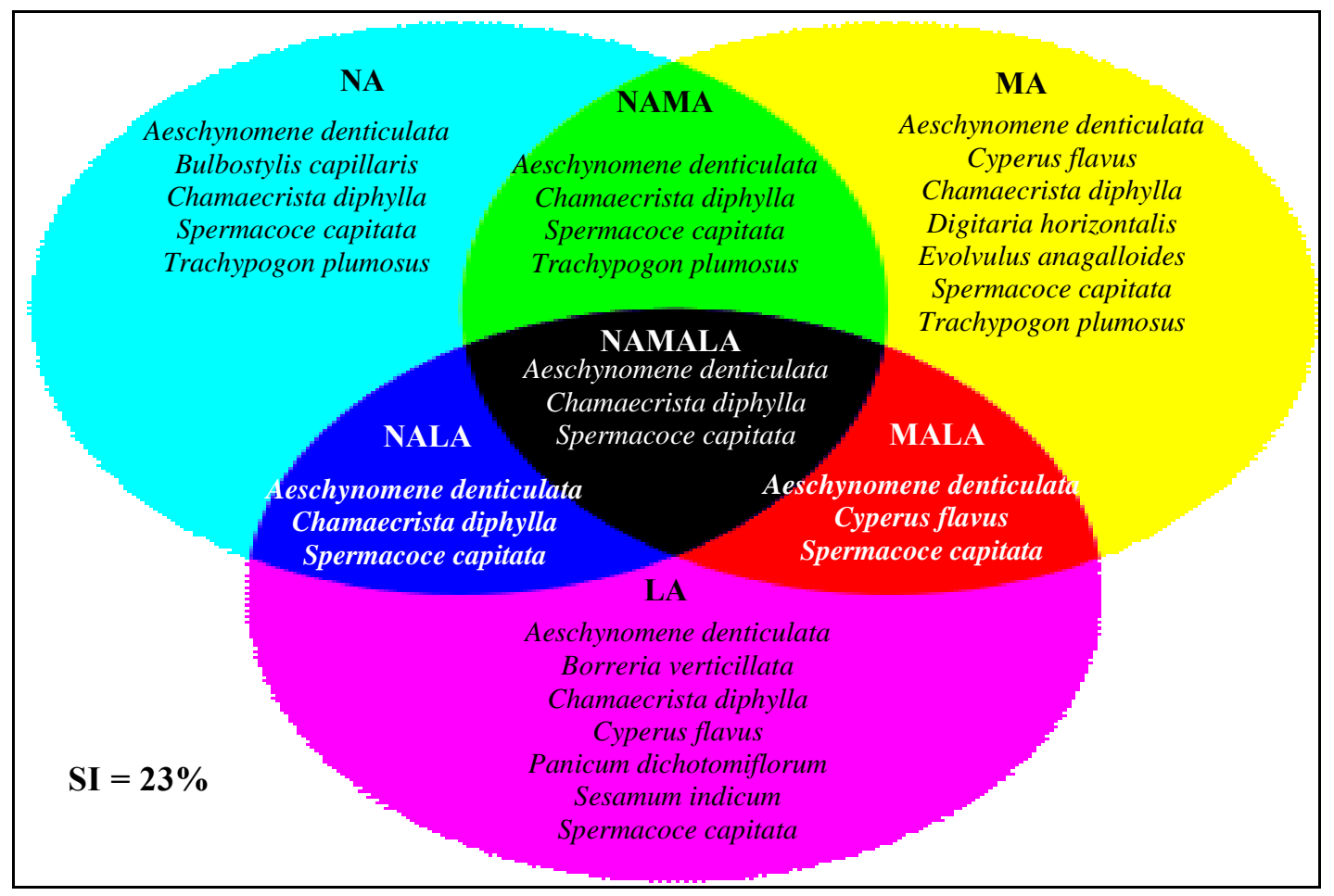

$\square$ Species collected in the native area

$\square$ Species collected in the mowed area

Species collected in the limed area

$\square$ Species in common collected in the native and mowed areas

Species in common collected in the native and limed areas

Species in common collected in the mowed and limed areas

- Species in common collected in the native, mowed, and limed areas

Figure 1 - Venn diagram and Sorensen similarity index (IS) adapted by the authors to illustrate 11 weed species collected in three distinct areas (native, mowed, and limed) in the Cerrado of Roraima in 2015/2016.

\section{RESULTS AND DISCUSSION}

Regarding the type of propagation, growth habit, and life cycle, the sexual, herbaceous, and annual characteristics prevailed, respectively. Among the species collected in the area, the botanical families Poaceae, Cyperaceae, Fabaceae, and Rubiaceae were the most representative 
(Table 2) with 3,2, 2, and 2 individuals per sampled area, respectively, representing 27.3\% (Poaceae), 18.2\% (Cyperaceae), 18.2\% (Fabaceae), and 18.2\% (Rubiaceae). In studies carried out by Marques et al. (2010), these families predominated in researches with cultivated species. The highest number of weeds belonging to the Poaceae family has a large number of diaspores, which facilitates their dissemination and, consequently, hinders their control (Lorenzi, 2008). This author observed that approximately $80 \%$ of the weeds present an herbaceous growth habit.

Table 2 - Botanical class, family, scientific name, common name, propagation type, growth habit, and life cycle of the species collected in the Cerrado areas of Roraima in 2015/2016

\begin{tabular}{|c|c|c|c|c|c|c|}
\hline Class & Family & Scientific name & Common name & $\begin{array}{c}\text { Propagation } \\
\text { type }\end{array}$ & Growth habit & Life cycle \\
\hline \multirow{6}{*}{ Magnoliopsida } & \multirow{6}{*}{$\begin{array}{l}\text { Fabaceae } \\
\text { Fabaceae } \\
\text { Convolvulaceae } \\
\text { Pedaliaceae } \\
\text { Rubiaceae } \\
\text { Rubiaceae }\end{array}$} & Aeschynomene denticulata & Jointvetch & Seed & Herbaceous & Annual \\
\hline & & Chamaecrista diphylla & Twoleaf sensitive pea & Seed & Herbaceous & Annual \\
\hline & & Evolvulus anagalloides & Dwarf morning glory & Seed & $\begin{array}{l}\text { Prostate } \\
\text { herbaceous }\end{array}$ & Annual \\
\hline & & Sesamum indicum & Sesame & Seed & Herbaceous & Annual \\
\hline & & Spermacoce capitata & Baldhead false buttonweed & Seed & Herbaceous & Annual \\
\hline & & Borreria verticillata & Shrubby false buttonweed & Seed & Herbaceous & Annual \\
\hline \multirow{5}{*}{ Liliopsida } & \multirow{5}{*}{$\begin{array}{l}\text { Cyperaceae } \\
\text { Cyperaceae } \\
\text { Poaceae } \\
\text { Poaceae } \\
\text { Poaceae }\end{array}$} & Bulbostylis capillaris & Densetuft hairsedge & Seed & Herbaceous & Annual \\
\hline & & Cyperus flavus & Inflatedscale flatsedge & Seed/rhizome & Herbaceous & Perennial \\
\hline & & Digitaria horizontalis & Jamaican crabgrass & Seed & Herbaceous & Perennial \\
\hline & & Trachypogon plumosus & Crinkleawn grass & Seed & Herbaceous & Perennial \\
\hline & & Panicum dichotomiflorum & Fall panicgrass & Seed & Herbaceous & Annual \\
\hline
\end{tabular}

According to Miranda and Absy (1997), Poaceae (Gramineae) are frequently found in weed surveys in Cerrado areas of northern South America, while Cyperaceae are much more frequent in the State of Roraima when compared to the Cerrado of Central Brazil. Among the various Poaceae species that compose the native pasture of the Cerrado of Roraima, Trachypogon plumosus is one of the most important, accounting for 70 to $90 \%$ of its botanical composition (Costa et al., 2014).

Flores and Rodrigues (2010) carried out similar studies in the Cerrado of Roraima and observed that $87 \%$ of the diversity of species found belongs to the Fabaceae family. Species of this family deserve attention because they fix nitrogen biologically and are consumed by animals.

Other studies carried out in the Cerrado of Roraima have confirmed the predominance of species of the Fabaceae family (Cruz et al., 2010; Flores and Rodrigues, 2010; Albuquerque et al., 2013, 2014). Alarcón and Peixoto (2007) carried out a phytosociological study in an area of 1 ha of upland forest in Roraima, in the municipality of Caracarai, and found that the Fabaceae family was the most representative with 32 species, which shows its prevalence in the natural environment and under spontaneous occurrence in a cultivated environment in the State of Roraima.

Species dynamics can vary in their floristic composition according to the type and intensity of used management practices, being able to alter the population and distribution of species within the community.

In the native area, the highest relative frequencies (Frr) were observed for the species T. plumosus (40.92\%), Bulbostylis capillaris (18.52\%), and Spermacoce capitata (18.33\%) (Table 3). According to Costa et al. (2013), T. plumosus were observed with great representativeness in an area of native pastures of the Cerrado of Roraima, with around $80 \%$ of its botanical composition. Studies have shown that forage yield of $T$. plumosus is variable and directly influenced by management practices and environmental conditions (Costa et al., 2011, 2013, 2014).

In the mowed area, the highest relative frequencies (Frr) were observed for the species T. plumosus (24.69\%), Cyperus flavus (24.69\%), and S. capitata (18.52\%) (Table 3). These species were favored by the mowing practice, which promoted their seed dissemination. According to Jakelaitis et al. (2003), for species that reproduce by seeds, the use of agricultural implements leads to the emergence of weeds, as well as their distribution in the area. 
MENEZES, P.H.S. et al. Occurrence of weeds in areas submitted to tillage managements for soybean cultivation in the Cerrado ...

Table 3 - Scientific name, dry matter (g), relative density (\%), relative frequency (\%), and relative dominance (\%) of species in the native area, mowed area, and limed area of the Cerrado of Roraima in 2015/2016

\begin{tabular}{|l|r|r|r|r|r|r|}
\hline \multicolumn{7}{|c|}{ Native area } \\
\hline \multicolumn{1}{|c|}{ Scientific name } & $\begin{array}{c}\text { DM* } \\
(\mathrm{g})\end{array}$ & $\begin{array}{c}\text { Drr } \\
(\%)\end{array}$ & $\begin{array}{c}\text { Frr } \\
(\%)\end{array}$ & $\begin{array}{c}\text { Dor } \\
(\%)\end{array}$ & $\begin{array}{c}\text { IVI } \\
(\%)\end{array}$ & $\begin{array}{r}\text { IVR } \\
(\%)\end{array}$ \\
\hline Aeschynomene denticulata & 2.26 & 3.2 & 11.11 & 0.45 & 14.78 & 4.93 \\
\hline Bulbostylis capillaris & 1.1 & 67.7 & 18.52 & 4.45 & 90.71 & 30.24 \\
\hline Chamaecrista diphylla & 4.8 & 3.2 & 11.11 & 0.95 & 15.28 & 5.09 \\
\hline Spermacoce capitata & 22.4 & 6.5 & 18.33 & 8.85 & 33.63 & 11.21 \\
\hline Trachypogon plumosus & 72.1 & 19.4 & 40.92 & 85.31 & 154.58 & 48.53 \\
\hline Total & 102.66 & 100.00 & 100.00 & 100.00 & 300.00 & 100.00 \\
\hline \multicolumn{7}{|c|}{ Mowed area } \\
\hline Aeschynomene denticulata & 8.68 & 1.59 & 7.41 & 5.94 & 14.94 & 4.98 \\
\hline Cyperus flavus & 1.2 & 44.44 & 24.69 & 23.08 & 92.22 & 30.74 \\
\hline Chamaecrista diphylla & 1.6 & 1.59 & 6.17 & 1.10 & 8.86 & 2.95 \\
\hline Evolvulus anagalloides & 1.6 & 1.59 & 6.17 & 1.10 & 8.86 & 2.95 \\
\hline Digitaria horizontalis & 0.7 & 39.68 & 12.35 & 11.81 & 63.84 & 2.28 \\
\hline Spermacoce capitata & 0.6 & 4.76 & 18.52 & 1.26 & 24.54 & 8.8 \\
\hline Trachypogon plumosus & 20.35 & 6.35 & 24.69 & 55.72 & 86.76 & 28.92 \\
\hline Total & 34.73 & 100.00 & 100.00 & 100.00 & 300.00 & 100.00 \\
\hline \multicolumn{7}{|c|}{ Limed area } \\
\hline Aeschynomene denticulata & 2.1 & 2.94 & 8.70 & 0.98 & 12.61 & 6.04 \\
\hline Borreria verticillata & 5.49 & 14.71 & 17.39 & 12.93 & 45.03 & 16.09 \\
\hline Chamaecrista diphylla & 0.53 & 1.47 & 4.35 & 0.12 & 5.94 & 4.10 \\
\hline Cyperus flavus & 0.95 & 57.35 & 26.09 & 8.73 & 92.17 & 41.84 \\
\hline Panicum dichotomiflorum & 66.12 & 1.47 & 4.35 & 15.58 & 21.39 & 4.10 \\
\hline Sesamum indicum & 41.99 & 8.82 & 21.74 & 59.35 & 89.91 & 12.78 \\
\hline Spermacoce capitata & 1.1 & 13.24 & 17.39 & 2.31 & 32.94 & 15.06 \\
\hline Total & 118.28 & 100.00 & 100.00 & 100.00 & 300.00 & 100.00 \\
\hline
\end{tabular}

$(\mathrm{DM})$ - dry matter; (Drr) - relative density; (Frr) - relative frequency; (Dor) - relative dominance; (IVI) - importance index value.

In the limed area, the highest relative frequencies (Frr) were observed for the species C. flavus (26.09\%), Sesamum indicum (21.74\%), and Borreria verticillata (17.39\%) (Table 3). The differentiated practice of soil management changes the frequency and species of weeds in cultivated areas (Lacerda et al., 2013; Lima et al., 2014).

According to Ferreira et al. (2007), the liming practice usually favors the increment of weeds in no-tillage systems, with a tendency to occur a higher incidence of these species, associating them with the $\mathrm{pH}$ and higher calcium content in the surface soil layer.

The species in common found in the areas were Aeschynomene denticulata, Chamaecrista diphylla, and S. capitata, showing that the used management did not influence the disappearance of them.

Cyperus flavus, Evolvulus anagalloides, Digitaria horizontalis, B. verticillata, Panicum dichotomiflorum, and $S$. indicum were observed after the management of the areas (mowed and limed areas), indicating that the used practices influenced their appearance. The variations in seed bank composition are directly associated with variations of edaphic variables, which are dependent on the management of the systems (Medeiros et al., 2006).

According to Marques (2015), among the identified species Cyperus spp., C. flavus showed the fourth and third highest IVI in the second and third agricultural years, respectively. These species were favored by the use of plow in those agricultural years, which promoted the dissemination of their seeds.

According to Albuquerque et al. (2013), for the agricultural scientist to be able to recommend appropriate management in an agricultural property, he/she must have a basic knowledge of 
several factors, including propagation methods, life cycle, growth habit, photosynthetic path, and knowing how to identify weed species, mainly in the young stage.

The calculated similarity index (SI) was 23\% (Figure 1). It is expressed in percentage, being maximum $(100 \%)$ when all species are common to the three areas and minimum $(0 \%)$ when there are no common species (Sørensen, 1972). This index allowed inferring the similar weeds existing in the three areas, demonstrating a low homogeneity. According to Felfili and Venturoli (2000), this index can be considered high when it exceeds $50 \%$.

In the Venn diagram (Figure 1), three species were common to the three areas: A. denticulata, C. diphylla, and S. capitata. For these species, the managements were indifferent to their presence in the sampled areas.

The comparison of the number of species in common carried out through the Venn diagram (Zar, 1999) (Figure 1) in the three areas (native, mowed, and limed) showed an unexpected result. These three areas presented a low similarity of weed species among them, some of them exclusive to each of the areas, such as $B$. capillaris in native area, E. anagalloides and $D$. horizontalis in the mowed area, and B. verticillata, $P$. dichotomiflorum, and $S$. indicum in the limed area.

In addition, the limed area presented the highest number of weeds possibly due to the soil disturbance during the limestone incorporation using agricultural implements, which allowed the emergence of present and viable seeds in the seed bank. In studies of weed phytosociology in soybean cultivation performed by Fialho et al. (2011), the genus Cyperus was present in higher quantities in different management systems, being observed its high density value and importance value index higher than that found for other species of the area.

The genus Cyperus has an asexual breeding system composed mainly of rhizomes and tubers, which contains a high nutrient reserve and guarantees the perpetuation and rapid reinfestation of agricultural areas submitted to the mechanical soil tillage. In the no-tillage system, it has a reduction in the density and accumulation rate of the shoot and tuber dry biomass, as well as a reduction of their viability in relation to populations that develop in the conventional tillage system (Fialho et al., 2011).

Moreover, the opening of extensive pasture and crop areas, especially soybean, reducing the natural areas, may favor the emergence of new species of spontaneous plants and weeds that have not yet been reported in the Cerrado of Roraima.

Thus, among the species collected in the areas, the botanical families Poaceae, Cyperaceae, Fabaceae, and Rubiaceae were more representative. The used managements did not influence the disappearance of the species A. denticulata, C. diphylla, and S. capitata. The species C. flavus, collected in the mowed and limed areas, had the highest values in all the assessed phytosociological parameters. The low homogeneity of weed species in common in the assessed areas showed that the used managements favored the emergence of new species of spontaneous plants and weeds in the Cerrado of Roraima.

\section{REFERENCES}

Alarcón JGS, Peixoto AL. Florística e fitossociologia de um trecho de um hectare de floresta de terra firme, em Caracaraí, Roraima, Brasil. Bol Mus Paran Emílio Goeldi. 2007;2:33-60.

Albuquerque JAA, Evangelista MO, Mates APK, Alves JMA, Oliveira NT, Sediyama T, et al. Occurrence of weeds in cassava savanna plantations in Roraima. Planta Daninha, 2014;32(1):91-8.

Albuquerque JAA, Melo VF, Soares MBB, Finoto EL, Siqueira RHS, Martins AS. Fitossociologia e características morfológicas de plantas daninhas após cultivo de milho em plantio convencional no cerrado de Roraima. Rev Agro@mbiente. 2013;7(3):313-21.

Benedetti UG, Vale Júnior JF, Schaefer CEGR, Melo VF, Uchôa SCP. Gênese, química e mineralogia de solos derivados de sedimentos pliopleistocênicos e de rochas vulcânicasbásicas em Roraima, norte da amazônico. Rev Bras Ci Solo, 2011;35(2):29912.

Brandão M, Brandão H, Laca-Buendia J.P. A mata ciliar do rio Sapucaí, município de Santa Rita do Sapucaí-MG: fitossociologia. Daphne, 1998;8(4):36-8. 
Brower JE, Zar JH. Field and laboratory methods for general ecology. 2a .ed. Iowa: Wm. C. Brown Company; 1984. 226p.

Companhia Nacional de Abastecimento - Conab. 2015. [acessado em: 11 de jun. 2017]. Disponível em: http://www.conab.gov.br/ conabweb/download/soja/produçao.pdf.

Costa NL, Moraes A, Gianluppi V, Bendahan AB. Avaliação da rebrota natural de pastagens de Trachypogon plumosus nos cerrados de Roraima. Sci Agr Paran. 2014;13:57-4.

Costa NL, Moraes A, Carvalho PCF, Monteiro ALG, Oliveira RA. Características morfogênicas e estruturais de Trachypogon plumosus de acordo com a fertilidade do solo e o nível de desfolha. Pesq Agropec Bras. 2013;48(3):320-8.

Costa NL, Moraes A, Oliveira RA, Gianluppi V, Bendahan AB, Magalhaes JA. Rendimento potencial de pastagens de Trachypogon plumosus nos cerrados de Roraima. Rev Agro@mbiente. 2011;5:200-6.

Cruz DLS, Rodrigues G, Dias FO, Alves J, Albuquerque JAA. Levantamento de plantas daninhas em área rotacionada com as culturas da soja, milho e arroz irrigado no cerrado de Roraima. Rev Agro@mbiente.2010;3(1):58-63

Flores AS, Rodrigues RS. Diversidade de Leguminosae em uma área de savana do estado de Roraima, Brasil. Acta Bot. Bras. 2010;24(1):175-83.

Felfili JM, Venturoli F. Tópicos em análise de vegetação. Brasília, DF: UnB, Departamento de Engenharia Florestal, 2000. (Comunicações Técnicas florestais, v.2, n.2)

Ferreira OGL, Siewerdt L, Medeiros RB, Levien R, Favreto R, Pedroso CES. Atributos químicos do solo e regeneração de espécies espontâneas originárias do banco de sementes em campo nativo sob diferentes sistemas de cultivo. Rev Bras Agroci. 2007;13(1):81-9.

Fialho CMT. Fitossociologia da comunidade de plantas daninhas na cultura da soja transgênica sob dois sistemas de preparo do solo. Sci Agr. 2011;12:9-17.

Gianluppi D, Smiderle O. Agricultura nos Cerrados de Roraima. Revista Plantio Direto. 2016. [acessado em: 19 maio 2017 ]. Disponível em: http://www.plantiodireto.com.br/?body=cont_int\&id=479.

Lacerda KLP, Cordeiro MAS, Verginassi A, Salgado FHM, Paulino HB, Carneiro MAC. Organic carbon, biomass and microbial activity in an Oxisol under different management systems. Rev Cienc Agr. 2013;56(3):249-54.

Lima SF. Fitossociologia de plantas daninhas em convivência com plantas de cobertura. Rev Caatinga. 2014;27:37-7.

Jakelaitis A, Ferreira LR, Silva AA, Agnes EL, Miranda GV, Machado AFL. Dinâmica populacional de plantas daninhas sob diferentes sistemas de manejo nas culturas de milho e feijão. Planta Daninha. 2003;21(1):71-9.

Lorenzi H. Plantas daninhas do Brasil: terrestres, aquáticas, parasitas e tóxicas. $4^{\mathrm{a}}$.ed. Nova Odessa: Plantarum; 2008. 640p.

Marques LJP, Silva MRM, Araújo MS, Lopes GS, Corrêa MJP, Freitas ACR, Muniz FH. Composição florística de plantas daninhas na cultura do feijão-caupi no sistema de capoeira triturada. Planta Daninha. 2010;28:953-61.

Marques LJP. Períodos de interferência das plantas daninhas na cultura da berinjela 'Nápoli' sem tutoramento e desbrota [tese]. Jaboticabal: Universidade Estadual Paulista; 2015.

MeloVF, Schaefer CEGR, Uchôa SCP. Indian land use in Raposa-Serra do solo reserve, Roraima, Amazônia, Brazil: physical and chemical attributes of a soil catena developed from mafic rocks under shifting cultivation. Catena. 2010;80:95-105.

Medeiros EV, Sales Júnior R, Michereff SJ, Barbosa MR. Quantificação de ascósporos de Monosporascus cannonballus em solos não cultivados de Caatinga e em áreas de cultivo de melão do Rio Grande do Norte e Ceará. Fitopatol Bras. 2006;31(5):500-4.

Miranda IS, Absy ML. A flora fanerogâmica das savanas de Roraima. In: Barbosa RI, Ferreira EJG, Castellõn EG, editores Homem, ambiente e ecologia no estado de Roraima. Manaus: INPA; 1997. p.445-62.

Sørensen T. A method of establishing groups of equal amplitude in plant society based on similarity of species content. In: Odum EP, editor. Ecologia. $3^{\text {rd }}$.ed. México: Interamericana; 1972.

Zar JH. Biostatistical analysis. $4^{\text {th }}$.ed. Upper Saddle River: Prentice Hall; 1999. 663p. 